\title{
O filho eterno: uma leitura desejante
}

\section{O filho eterno.}

TEZZA, Cristovão.

Rio de Janeiro: Record, 2007.

O romance $O$ filho eterno, de Cristovão Tezza, conta a história do amadurecimento de um homem com o nascimento de seu primeiro filho, uma criança com Síndrome de Down. A crítica literária de língua inglesa, sempre preocupada em 'fichar' um romance, chama esse gênero literário de coming-of-age novel ou bildungsroman. No entanto, na orelha do livro somos informados de que o escritor, Cristovão Tezza, baseia a história em sua própria vida, logo, um romance autobiográfico: "Num livro corajoso, Cristovão Tezza expõe as dificuldades, inúmeras, e as saborosas pequenas vitórias de criar um filho com síndrome de Down". Folheando as primeiras páginas encontramos as epígrafes:
Queremos dizer a verdade e, no entanto, não dizemos a verdade. Descrevemos algo buscando fidelidade à verdade e, no entanto, o descrito é outra coisa que não a verdade. ${ }^{1}$ Um filho é como um espelho no qual o pai se vê, e, para o filho, o pai é por sua vez um espelho no qual ele se vê no futuro. ${ }^{2}$

A primeira fala sobre 'verdade' e a impossibilidade de a verdade ser apreendida mesmo quando a intenção é revelar a verdade. A segunda fala sobre ser pai e ser filho. Antes mesmo de iniciar a leitura, somos informados de que o romance tem como ponto de partida as memórias do escritor Cristovão Tezza, e, ele mesmo, na epígrafe, deixa claro que memórias são essas. Uma história baseada em fatos reais que não tem pretensão de ser a verdade. É a história do relacionamento de pai e filho - e, pela orelha do livro, somos informados de que se trata de um relacionamento com "dificuldades, inúmeras, e as saborosas pequenas vitórias". Além disso, trata-se de um "livro corajoso" - o escritor é considerado corajoso ao relatar parte de sua vida, ao expor sua família e sua 
intimidade. Porém, confesso que me incomoda adjetivar o livro (e o escritor) de "corajoso", pois "ser corajoso" me remete a livros com relatos (dramáticos) de histórias pessoais - "histórias de coragem e conquistas" - bem nos moldes do mote (ou mantra?) da propaganda política do governo: "sou brasileiro e não desisto nunca". Talvez só eu tenha feito essa relação mental (que foi automática e com uma pitada de arrogância, admito), mas, de qualquer maneira, ler "livro corajoso" na orelha não me impediu, nem me desanimou, de ler o livro - a epígrafe me deu a impressão de que não se tratava de mais um "relato de coragem e determinação". Claro que essa orelha foi escrita com propósitos comerciais, afinal, toda história e todo filme "baseados em fatos reais" encontram um certo apelo público. A ideia de alguém que viveu momentos difíceis e superou, ou que não superou, mas o final infeliz nos ensina a valorizar a vida e os momentos felizes. Coincidentemente, enquanto eu lia o livro e comentava, durante um almoço com uma amiga, a resposta dela foi: "Ah sei! Vi uma entrevista do autor e esse é o livro que ele escreveu sobre o filho com Down né? Anotei pra comprar. É uma história bonita?". Respondi: "Bonita? Hmm... define 'bonita'" (ela não quis ou não soube ou não vinha ao caso naquele almoço). Na hora, eu me lembrei do texto "O valor", de Antoine Compagnon, ${ }^{3} \mathrm{e}$, automatica-mente, vários outros textos foram pipocando na minha cabeça, textos sobre belo, estilo, estética, conceito de literário etc., como o do Ítalo Moriconi, "Circuitos contemporâneos do literário (indicações de pesquisa)". ${ }^{4}$

Essa conversa apresenta parte da reflexão de Moriconi sobre o conceito de literário na atualidade. Para Moriconi, o processo material de criação da obra literária (ou obra de ficção), bem como a personalidade e a vida do autor desempenham papel determinante na divulgação, recepção de obras literárias (e artísticas) contemporâneas. Poderíamos aqui citar a presença do website do escritor Cristovão Tezza na orelha da contracapa do livro, após a breve informação biográfica. $O$ culto à personalidade do autor e como esta aparece na obra estão implícitos nesse novo detalhe de algumas edições recentes. Como se, sob o aval da editora Record, o leitor obtivesse o endereço eletrônico de "um website oficial" - aos moldes de personalidades tornadas celebridades no mundo virtual, com inúmeros websites de fãs e com o respeitado website oficial.

Se na esfera pública clássica, pré-midiática, o autor era um "ser de papel" (como dele disse
Barthes), ser virtual no sentido original da palavra virtual e não no sentido de virtual on line, hoje esse autor está disponível para apresentar seus materiais de trabalho, de tal maneira que a esfera do específico estético incorporou o making of como elemento de consideração. [...] Considero que textos de depoimentos de artistas e de entrevistas sobre suas trajetórias biomateriais constituem corpus que fazem parte do conceito de literário atualmente. $\dot{E}$ que faz parte da definição de arte e literatura - objeto que se coloca em cena como representação do processo material de criação, como simulacro de uma situação de enunciação. ${ }^{5}$

Dispersa parcialmente da conversa, comecei a pensar sobre o meu adjetivo para aquela narrativa, aquele texto de ficção, texto literário, romance, romance autobiográfico. Sentei na frente do computador e comecei a escrever minha resenha. Meu adjetivo: sincero. Um livro sincero, um narrador sincero, uma história sincera. Sem pieguice, sem conquistas descritas em tom meloso, sem lágrimas fáceis de "histórias bonitas" - mas lágrimas sinceras de confissões que podem ser recebidas como um soco no estômago. A subversão de expectativas sociais em relação à paternidade: logo no início temos um pai que deseja secretamente a morte do filho assim que ele nasce. Durante todo o livro o leitor é confrontado com desejos e pensamentos 'egoístas' de um personagem, e esses fazem o leitor, a todo momento, pensar em seus desejos íntimos e secretos. A coragem aqui aparece nas revelações secas e cruéis dos desejos mais secretos de um personagem que não procura se redimir. $E$ isso, para mim como leitora, é a força do romance. A preocupação do personagem em não se conformar, em não fazer parte de um sistema e em não ser mais um "idiota" é refletida na narrativa, que em nenhum momento se conforma aos moldes das narrativas "corajosas".

O filho eterno é uma narrativa seca de desencantamento, em terceira pessoa, onde os personagens não têm nome, com exceção do filho, Felipe, e são chamados de "ele", "o pai", "a mulher", "a mãe", "a filha", "a irmã". Mesmo Felipe frequentemente aparece como "o filho" em contraposição ao "pai". Não encontramos o lugar-comum, o apelo ao sentimento de pena e empatia, e, acredito, ser isso uma das qualidades de uma história que prende o leitor por não fornecer respostas e soluções óbvias, pelo contrário, a surpresa é uma constante durante a leitura. Percorremos a trajetória 
do personagem pai e, dentro de sua história, acompanhamos a trajetória do personagem filho, Felipe. $O$ treinamento neurológico nos primeiros anos de vida do filho é contrastado com o 'treinamento' do pai em relação às tentativas de publicar seus livros e as recusas das editoras:

Eu também estou em treinamento, ele pensa, lembrando mais uma recusa de editora. A vida real começa a puxá-lo com violência para o chão, e ele ri imaginando-se no lugar do filho, coordenando braços e pernas para ficar em pé no mundo com um pouco mais de segurança (p. 130).

O crescimento e o desenvolvimento do filho são percebidos pelo pai nas representações de papéis sociais que o filho se esforça em cumprir (p. 211). Ao mesmo tempo, o pai descobre a alegria que a rotina traz e a tranquilidade conquistada com papéis sociais como "o professor universitário", "o escritor".

"O pai começa a descobrir sinais de maturidade no seu Peter Pan e eles existem, mas sempre como representação" (p. 218). O espelho no qual ambos, pai e filho, se veem é o espelho que reflete a representação dos papéis sociais. A percepção de mimetismo social no filho não está muito distante dos papéis que o pai é solicitado a cumprir socialmente na universidade, na família, na escola do filho, no campeonato de natação e na apresentação de teatro do filho. A dificuldade do pai é tão grande quanto a dificuldade do filho. A criança que vive eternamente no presente aprende a responder ao que é solicitado dela socialmente. O pai provisório, que só pensava em viver o presente, também aprende. E aqui é revelado o escritor por trás da narrativa. A sutileza ao contar os episódios na vida do pai e do filho é alcançda no contar da história, pois não há momentos de avaliação e reflexão em que paralelos são explicitamente estabelecidos. Esse trabalho é reservado ao leitor. $E$ nesse momento me veio à cabeça um texto do qual eu gosto muito: "Freud's Masterplot", de Peter Brooks. ${ }^{6}$

Nesse texto, Brooks cria uma "teoria da narrativa" baseada no que ele chama de "teoria da vida", criada por Freud em Além do princípio do prazer e baseada na leitura de Lacan dos conceitos freudianos de condensação e deslocamento, com seus análogos na linguagem, metáfora e metonímia, respectivamente. Se viver é a separação entre o nascimento e a morte, o meio da narrativa é o que separa o início do fim (sendo ambos, a morte e o fim, já presentes no nascimento e no início do texto). Sendo assim, resta ao indivíduo e ao leitor percorrer esse caminho árduo e prazeroso, evitando atalhos. Para Brooks, o meio do texto (o texto em si) é o local onde alguma forma de energia textual é ativada pelo leitor na interação entre leitor e texto. Na ficção, o perigo dos atalhos e da "morte repentina" é tarefa do escritor criador da narrativa e do leitor, que precisa ligar as redes metonímicas para alcançar a metáfora. Acredito que há no romance de Tezza essa preocupação em não deixar o leitor "morrer de repente", ou, como indaga Roland Barthes sobre o prazer de ler, não abandonar o texto. E chego ao Barthes.

Em "Da leitura", Barthes questiona a existência de um prazer de leitura, um prazer de ler, e conclui que existem, pelo menos, "três vias pelas quais a Imagem de leitura pode capturar o sujeito-leitor": a) o estabelecimento de uma relação fetichista entre o leitor e o texto; b) "o prazer metonímico de toda narração"; e c) a leitura como condutora do desejo de escrever, desejo de Escritura. ${ }^{7}$ A leitura de $O$ filho eterno foi, para mim, uma leitura permeada pelos três desejos destacados por Barthes. Como sujeitoleitor, passei de um "dever de leitura" para as vias assinaladas por Barthes, e, pessoalmente, foi o "prazer metonímico" da narrativa de Cristovão Tezza que tornou a leitura especial, uma "leitura desejante".

\section{Notas}

\footnotetext{
1 Thomas BERNHARD apud Cristovão TEZZA.

${ }^{2}$ Søren KIERKEGAARD apud TEZZA.

${ }^{3}$ Antoine COMPAGNON, 2001

4 Ítalo MORICONI, 2006.

5 Ítalo MORICONI, 2006, p. 161-162.

${ }^{6}$ Peter BROOKS, 2007.

${ }^{7}$ Roland BARTHES, 1988, p. 49.
}

\section{Referências bibliográficas}

BARTHES, Roland. "Da leitura". In: Orumor da língua. São Paulo: Brasiliense, 1988. p. 43-52.

BROOKS, Peter. "Freud's Masterplot". In: RICHTER, David H. (Ed.). The Critical Tradition. Boston: Bedford; St. Martin's, 2007. p. 1161-1171.

COMPAGNON, Antoine. "O valor". In: . demônio da teoria: literatura e senso comum. Belo Horizonte: UFMG, 2001. p. 225-255.

MORICONI, Ítalo. "Circuitos contemporâneos do literário (indicações de pesquisa)". Revista Gragoatá, Niterói, n. 20, p. 147-163, 1. sem. 2006.

Marina Barbosa de Almeida Universidade Federal de Santa Catarina 